\title{
Enneking Surgical Grade
}

National Cancer Institute

\section{Source}

National Cancer Institute. Enneking Surgical Grade. NCI Thesaurus. Code C140259.

A description of malignant mesenchymal tumors based on cell morphological features. 